\title{
Endoscopic findings of the gastrointestinal tract and conjunctions with preceding tomography findings
}

\section{Gastrointestinal sistemin endoskopik bulguları ve tomografi bulguları ile ilişkisi}

Mehmet Alperen Avc1 ${ }^{*}$, Engin Ölçücüoğlu², İsmail Oskay Kaya², Serra Özbal Güneş ${ }^{3}$ Cem Azıl1², Metin Aydin ${ }^{2}$

1. Sorgun State Hospital, Department of General Surgery, Yozgat, Turkey

2.University of Health Sciences Dışkapı Yıldirım Beyazıt Teaching and Research Hospital, Department of General Surgery, Ankara, Turkey

3.University of Health Sciences Dışkapı Yıldırım Beyazıt Teaching and Research Hospital, Department of Radiology, Ankara, Turkey

\section{ABSTRACT}

Aim: Abdominopelvic computed tomography is commonly used for delineating the causes of abdominal pain. While its popularity has increased, the rate of nonspecific findings like gastrointestinal wall thickening has also increased. We aimed to determine whether a CT finding of thickened wall predicted a pathological finding on subsequent endoscopic evaluation.

Method: This retrospective study was conducted on adult patients who underwent endoscopic or colonoscopic evaluation at our center in 2019 and had a preceding abdominopelvic CT within a month before this investigation. Patients' gastric or colonic wall thicknesses were measured during CT scans. Endoscopy or colonoscopy results of these patients were retrieved, and their correlation with wall thicknesses was analyzed.

Results: The study cohort included 647 patients. While 106 (16.38\%) underwent endoscopy, $541(83.62 \%)$ underwent colonoscopy. The endoscopic biopsies were malignant in 101 patients $(95,3 \%)$ and benign in $5(4,7 \%)$ patients. The CT sections showed thickened wall in $93(87.7 \%)$ patients. Comparison of the patients with and without a thickened wall revealed no difference concerning malignancy rates. Increased colonic wall thickness was detected in $506(93,5 \%)$ of the CT sections. Normal or benign colonoscopic biopsy findings were reported in $19(3,5 \%)$ patients. Adenocarcinoma was detected in $456(84,2 \%)$ patients. Comparison of the patient groups with or without wall thickening did not reveal any significant differences regarding malignancy rates.

Conclusion: Endoscopic-colonoscopic evaluations should be performed in patients with gastrointestinal wall thickening in CT scans since the diagnostic and predictive accuracy are limited when a single test like CT is used.

Keywords: Endoscopy, Colonoscopy, Wall thickening, Abdominal Computed Tomography

\section{ÖZ}

Amaç: Abdominopelvik bilgisayarlı tomografi, karın ağrısı nedenlerini belirlemek için yaygın olarak kullanılmaktadır. Tomografinin popülaritesi artarken gastrointestina duvar kalınlaşması gibi nonspesifik bulguların oranı da artmıştır. Duvar kalınlığı artışının, endoskopik değerlendirmede patolojik bir bulguyu tahmin edip etmediğin belirlemeyi amaçladık.

Yöntemler: Bu retrospektif çalışma, 2019 yilında merkezimizde endoskopik veya kolonoskopik değerlendirme yapılan ve bu incelemeden önceki bir ay içinde abdominopelvik tomografi yapılan erişkin hastalar üzerinde yapıımıştır. Tomografi taramaları sırasında hastaların mide veya kolon duvar kalınlıkları ölçüldü. Bu hastaların endoskopi veya kolonoskopi sonuçları alınarak duvar kalınlıkları ile korelasyonları incelenmiş̧tir.

Bulgular: Çalışma 647 hastayı içeriyordu. 106'sına (\%16.38) endoskopi yapilırken, 541 'ine (\%83.62) kolonoskopi yapıldı. Endoskopik biyopsiler 101 hastada (\%95,3) malign, $5(\% 4,7)$ hastada benign idi. BT kesitlerinde $93(\% 87.7)$ hastada kalınlaşmış duvar görüldü. Duvar kalınlık artışı olan ve olmayan hastaların karşılaştıııması, malignite oranları açısından farklılık göstermedi.BT kesitlerinin 506 'sında $(\% 93,5)$ kolon duvar kalınlığında artış saptandı. $19(\% 3,5)$ hastada normal veya benign kolonoskopik biyopsi bulguları rapor edildi. $456(\% 84,2)$ hastada adenokarsinom tespit edildi. Duvar kalınlık artışı olan ve olmayan hasta gruplarının karşılaştıııması malignite oranları açısından anlamlı bir farklılık ortaya koymadı.

Sonuçlar: Tomografi gibi tek bir test kullanıldığında tanısal ve prediktif doğruluk sınırı olduğundan tomografi taramalarında gastrointestinal duvar kalınlaşması olan hastalarda endoskopik-kolonoskopik değerlendirmelerl de ek olarak yapılmalııır.

Anahtar Kelimeler: Endoskopi, Kolonoskopi, Duvar Kalınlığı, Bilgisayarlı Tomografi

Received: 21.04.2021 Accepted: 08.10.2021 Published (Online):31.12.2021

*Corresponding Author: Mehmet Alperen Avc1, Sorgun State Hospital, Department of General Surgery, Yozgat,Turkey, +905532158698,dr.maavci@gmail.com

ORCID ID:0000-0003-3911-2686

To cited: Avcı MA, Olcucuoglu E, Kaya IO, Gunes Ozbal S, Azılı C, Aydın M. Endoscopic Findings of the Gastrointestinal Tract and Conjunctions with Preceding Tomography Findings. Acta Med Alanya 2021;5(3):301-307 doi: $10.30565 /$ medalanya. 924320 


\section{INTRODUCTION}

$\mathrm{C}$ omputed tomography (CT) has become a common imaging technique for delineating the causes of abdominal pain. Its popularity has increased as a result of its advanced proficiency, improved resolution and image precision [1]. Conjointly, the rate of non-specific findings has also increased with the frequent use of $C T$. These non-specific findings are sometimes difficult to interpret by clinicians [2]. One of these findings is the visceral wall thickening, either at the upper or lower gastrointestinal tract. While some incidental reports of wall thickening may represent normal findings, some minor changes could be an early sign of malignancy $[3,4]$.

In this era of frequent CT imaging, it is common to be faced with such dilemmas and the soundest way to resolve this problem is to perform endoscopic and colonoscopic evaluations, where the entire gastrointestinal tract can be screened and biopsied if necessary [5]. However, this approach is not feasible for a number of patient groups, namely the elderly with their multiple comorbidities and high frailty scores [6]. Invasive interventions can lead to high procedure-related complications and poor outcomes in this group [7, 8]. On the other hand, an endoscopic evaluation for young and healthy patients may have a low yield for delineation of gastrointestinal wall thickening detected in CT.

Several clinical trials have attempted to solve this dilemma by investigating the correlation of wall thickness observed in CT scans with those patients' endoscopic findings [9-12]. However, this approach might have led to a selection bias: in these patients, the clinician may have been prompted to perform an endoscopic evaluation in which he sought to find a pathological explanation to the CT findings. To prevent a potential selection bias, we considered a different approach in our study. We reviewed all the patients who underwent endoscopic or colonoscopic evaluations at our general surgery clinic. Subsequently, we reviewed our institution's CT image repository to see if these patients had a preceding CT performed within one month. Thus, we were able to form a study cohort consisting of symptomatic patients, who presented with a wide range of gastrointestinal symptoms, representing the actual patient population encountered at general surgery and gastroenterology clinics. We sought to determine whether a CT finding of thickened gastrointestinal wall predicted a pathological finding on subsequent endoscopic evaluations, through the analysis of this population.

\section{MATERIALS AND METHODS}

\section{Study Population}

This study was designed as a retrospective clinical study performed on adult patients who underwent endoscopic or colonoscopic evaluation of the gastrointestinal tract and had a preceding computed tomography of the abdomen within a month prior to this investigation. The study was conducted between January 2019 and December 2019 in Diskapi Training and Research Hospital, Department of General Surgery. It was approved by the Ethical Review Committee of the same hospital $(12.11 .2018,56 / 12)$. All flexible endoscopy or colonoscopy procedures were performed using a Fujinon $®$ Japan, 2008, EC 450 HL5 Colonoscopy device and Fujinon 2009 EG 250PE5 Gastroscopy device, by surgeons with at least 5 years of experience in colonoscopy and endoscopy, and biopsies were taken from suspicious areas or areas with overt disease. In cases where no overt disease or suspicious areas were observed, random biopsies were taken according to our institutional protocol.

Patients with insufficient bowel cleansing or a suboptimal colonoscopy were excluded based on previously dictated colonoscopy reports (i.e., patients necessitating re-evaluation). All patients included in the study cohort had a helical CT with intravenous contrast medium (Omnipaque ${ }^{\circledR}$; OPAKIM Medical Products Industry and Trade Inc., Istanbul, Turkey), and all CT scans were performed with a slice thickness of $5-\mathrm{mm}$. Patients without a preceding intravenous contrast CT scan, those who had inadequate distension of the gastrointestinal tract, patients who had systemic diseases such as chronic kidney failure or heart failure, and those patients under the age of eighteen were all omitted. Additionally, patients with a history of previous abdominal surgery or patients with a known gastrointestinal disease were also omitted. Abdominal CT sections of the patients were re-evaluated by radiologists with 
at least 5 years of experience, blinded to the endoscopic evaluations of those patients.

Gastrointestinal wall thicknesses on the CT sections were measured individually, and a width of 0-5 mm was considered normal, whereas a width of more than $5 \mathrm{~mm}$ was considered "increased wall thickness". Patients were classified into two main groups according to the presence of colonic wall thickening. These two groups were analyzed and compared regarding patient characteristics and histopathology results. For further analysis, CT findings were classified according to the grade of segmental wall thickening: while 0-5 $\mathrm{mm}$ was considered standard thickness, 5-20 $\mathrm{mm}$ was defined as moderately increased, and 20-60 mm was considered severely increased thickness (Figures 1 and 2). Patients with diffuse wall thickening were also identified. Patients were analyzed separately in endoscopy and colonoscopy groups.
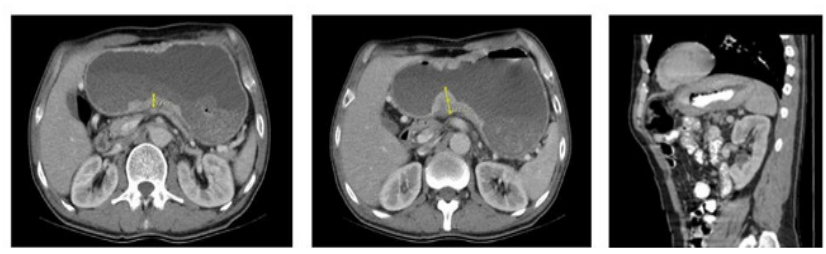

Figure 1: Grades of gastric wall thickening on computed tomography images. A- Moderate $(5-20 \mathrm{~mm})$ thickening B- Severe $(20-60 \mathrm{~mm})$ thickening $\mathrm{C}$ - Diffuse wall thickening
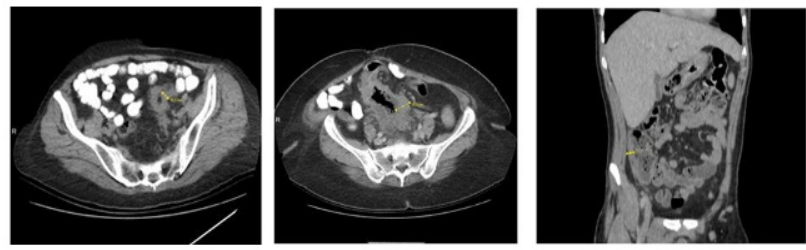

Figure 2: Grades of colonic wall thickening on computed tomography images A- Moderate $(5-20 \mathrm{~mm})$ wall thickening of the sigmoid wall B- Severe (20-60 mm) thickening of the sigmoid wall C-Diffuse wall thickening in the caecum and ascending colon

\section{Statistical Analysis}

Data analysis was performed using the IBM SPSS Statistics 17.0 (IBM Corporation, Armonk, NY, USA) package program. The KolmogorovSmirnov test was used to examine whether the distribution of discrete numerical variables was close to normal. The assumption of homogeneity of variances was investigated using Levene's test. For descriptive analysis, numerical variables were expressed as means \pm standard deviations, while categorical variables were given as numbers of cases and percentages. The significance of the difference between more than two independent groups was evaluated with Student's t-test and one-way analysis of variance (ANOVA). The categorical data was evaluated by Fisher's exact result probability test, while the Continuity Corrected Chi-Square test was used when the expected frequency was between 5-25. Otherwise, the Pearson test was performed. The $p$ value was considered statistically significant when it was less than 0.05 .

\section{RESULTS}

A total of 647 patients had undergone an endoscopic or colonoscopic evaluation at our endoscopy unit during the study period. All of these patients had undergone a preceding abdominal CT within one month of the evaluation. The male gender was predominant, with $414(63,9 \%)$ male patients in the study cohort. The patients' demographic characteristics, including chief complaints and duration of symptoms, are displayed in Table 1. One hundred and six $(16.38 \%)$ patients had undergone an endoscopy, while $541(83.62 \%)$ had undergone a colonoscopy. Among the patients who underwent an endoscopy, the most common chief complaint was dyspepsia $(n=60,56,6 \%)$ and for those who underwent a colonoscopy, the most frequent chief complaint was an unexplained change in bowel habits $(n=389,71,9 \%)$. The mean duration of symptoms was $33 \pm 5$ days.

Table 1. Demographic characteristics of the study patients

\begin{tabular}{|l|c|c|}
\hline Mean age (years) & $61.6 \pm 13.9$ & \\
\hline Gender & $\mathrm{N}=647$ & $(\%)$ \\
\hline Male & 414 & 63.38 \\
\hline Female & 233 & 83.72 \\
\hline Chief complaints before endoscopy & $\mathrm{N}=106$ & $(\%)$ \\
Dyspepsia & 60 & 56.60 \\
Weight Loss & 53 & 50.00 \\
Dysphagia & 23 & 21.69 \\
& & \\
& $\mathrm{~N}=541$ & $(\%)$ \\
Unexplained change in bowel habits & 389 & 71.90 \\
Bloating- abdominal cramps & 258 & 47.69 \\
Lower gastrointestinal bleeding & 112 & 20.70 \\
Mean duration of symptoms & & \\
& \multicolumn{2}{|c|}{$33 \pm 5$ days } \\
\hline
\end{tabular}

The median age was $60.3 \pm 13.1$ years in the endoscopy group and there were 66 (62,3\%) males and $40(37,7 \%)$ females in this patient 
group. The evaluations revealed that most endoscopic lesions were located in the stomach's antrum $(n=56,52,8 \%)$. This was followed by corpus $(n=45,42,5 \%)$, cardia $(n=26,24,5 \%)$ and fundus $(n=9,8,5 \%)$. Seven $(6,6 \%)$ patients were reported to have lesions at the lower esophagus. The endoscopic biopsies were malignant in 101 patients $(95,3 \%)$ and benign in $5(4,7 \%)$ patients. The most common pathology was adenocarcinoma $(n=71,66,9 \%)$. Signet ring cell carcinoma, malignant epithelial tumors and neuroendocrine tumors were detected in $16(15,1 \%), 8(7,5 \%)$, and $3(2,8 \%)$ of these patients, respectively (Table 2$)$.

Table 2. Biopsy results of the patients in the endoscopy group

\begin{tabular}{|l|l|l|}
\hline Endoscopic biopsy results & $(\mathrm{n}=106)$ & $(\%)$ \\
\hline Adenocarcinoma & 71 & 66.9 \\
\hline Signet ring cell carcinoma & 16 & 15.1 \\
\hline Malignant epithelial tumor & 8 & 7.5 \\
\hline Neuroendocrine tumor & 3 & 2.8 \\
\hline Squamous cell tumor & 1 & 0.9 \\
\hline Gastrointestinal stromal tumor & 1 & 0.9 \\
\hline $\begin{array}{l}\text { Mixed (Adenocarcinoma and Signet cell } \\
\text { carcinoma) }\end{array}$ & 1 & 0.9 \\
\hline Benign & 5 & 4.7 \\
\hline
\end{tabular}

A review of these 106 patients' CT sections showed thickened wall in $93(87.7 \%)$ patients. The CT sections of the remaining $13(12.3 \%)$ patients were normal. Comparison of the patients with and without a thickened wall on CT scan revealed no difference concerning age, gender distribution and malignancy rates $(p=0.976, p=0.231, p=0.487$, respectively) and are presented in Table 3 . The analysis regarding lesion locations elucidated that CT findings and endoscopic findings overlapped in 70 patients $(66,03 \%)$. However, in $23(21,7 \%)$ patients, the location information showed no conjunction between endoscopy and $\mathrm{CT}$. Classification of the patients concerning the grade of wall thickening revealed that wall thickness was normal in $13(12,3 \%)$, moderately increased in $16(15,1 \%)$ and severely increased in $13(12,2 \%)$ patients. Sixty-four $(60,4 \%)$ patients had diffusely increased wall thickness. There was no difference between these patient subgroups concerning patient age and malignancy rates $(p=0.656, p=0.344)$. On the other hand, there was a statistically significant difference between these subgroups regarding gender distribution $(p=0.049)($ Table 3$)$.
Table 3. Comparison of the endoscopy results and patient demographics based on the presence and grade of wall thickening

\begin{tabular}{|l|l|l|l|}
\hline $\begin{array}{l}\text { Presence of thickened } \\
\text { wall }\end{array}$ & Age (years) & $\begin{array}{l}\text { Male/Female } \\
(\mathrm{n})\end{array}$ & $\begin{array}{l}\text { Benign/ } \\
\text { Malignant }(\mathrm{n})\end{array}$ \\
\hline -No & $60.4 \pm 11.2$ & $6 / 7$ & $1 / 12$ \\
\hline -Yes & $60.3 \pm 13.4$ & $60 / 33$ & $4 / 89$ \\
\hline p-value & 0.976 & 0.231 & 0.487 \\
\hline $\begin{array}{l}\text { Grade of wall } \\
\text { thickening }\end{array}$ & Age (years) & $\begin{array}{l}\text { Male/Female } \\
(\mathrm{n})\end{array}$ & $\begin{array}{l}\text { Benign/ } \\
\text { Malignant }(\mathrm{n})\end{array}$ \\
\hline -Normal $(0-5 \mathrm{~mm})$ & $60.4 \pm 11.2$ & $6 / 7$ & $1 / 12$ \\
\hline -Moderate $(5-20 \mathrm{~mm})$ & $59.6 \pm 13.3$ & $10 / 6$ & $0 / 16$ \\
\hline -Severe $(20-60 \mathrm{~mm})$ & $56.2 \pm 11.7$ & $12 / 1$ & $0 / 13$ \\
\hline $\begin{array}{l}\text { Diffuse wall } \\
\text { thickening }\end{array}$ & $61.3 \pm 13.8$ & $38 / 26$ & $4 / 60$ \\
\hline p value & 0.656 & 0.049 & 0.344 \\
\hline
\end{tabular}

The mean patient age was $62.7 \pm 12.7$ years in the colonoscopy group (Table 5). Among the 541 patients included in this group, $348(64,3 \%)$ were males and $193(35,7 \%)$ were females. Normal colonoscopic findings were detected in $8(1,5 \%)$ patients. The colonoscopic evaluations revealed that $158(29,2 \%)$ patients had lesions in the rectum, $91(16,8 \%)$ patients in the sigmoid colon and 53 $(9,8 \%)$ patients in the caecum. On the other hand, $37(6,8 \%)$ patients had lesions in the ascending colon, $35(6,5 \%)$ patients in the descending colon, $35(6,5 \%)$ patients in the hepatic flexure, $27(5 \%)$ patients in the splenic flexure and 20 (3.7\%) patients in the transverse colon. Increased colonic wall thickness was detected in $506(93,5 \%)$ of the CT sections. Analysis of the CT findings and colonoscopic lesion locations revealed that they overlapped in $432(79,8 \%)$ patients $(p=0.082)$.

Normal or benign colonoscopic biopsy findings were reported in $19(3,5 \%)$ patients. Adenocarcinoma was detected in $456(84,2 \%)$, adenoma (tubular/ villous) in $36(6,6 \%)$, mucinous adenocarcinoma in $21(3,8 \%)$ and signet cell carcinoma was detected in $8(1,4 \%)$ patients. Squamous cell carcinoma was diagnosed in 1 patient $(0,2 \%)$ (Table 4 ). Comparison of the patient groups with or without wall thickening did not reveal any significant differences regarding age, gender distribution and malignancy rates $(p=0.578, p=0.469, p=0.13$, respectively) (Table 5).

Thirty-four $(6,2 \%)$ patients had standard colonic wall measures. Colonic wall thickness was moderately increased in $61(11,2 \%)$, severely 
increased in $42(7,7 \%)$ and diffusely increased in $394(72,8 \%)$ patients. There was no difference between the patient subgroups with different colonic wall thicknesses regarding patient age, gender distribution and malignancy rates $(p=0.833$, $p=0.147, p=0.528$, respectively) (Table 5).

Table 4. Biopsy results of the patients in the colonoscopy group

\begin{tabular}{|l|l|l|}
\hline Colonoscopic biopsy results & $(\mathrm{n}=541)$ & $(\%)$ \\
\hline Adenocarcinoma & 456 & 84.2 \\
\hline Adenoma (tubular/villous) & 36 & 6.6 \\
\hline Mucinous adenocarcinoma & 21 & 3,8 \\
\hline Normal findings/benign conditions & 19 & 3.5 \\
\hline Signet cell carcinoma & 8 & 1.4 \\
\hline Squamous cell tumor & 1 & 0.2 \\
\hline
\end{tabular}

Table 5. Comparison of the colonoscopy patients based on presence and grade of wall thickening

\begin{tabular}{|l|l|l|l|}
\hline $\begin{array}{l}\text { Presence of thickened } \\
\text { wall }\end{array}$ & Age (years) & $\begin{array}{l}\text { Male/Female } \\
(\mathrm{n})\end{array}$ & $\begin{array}{l}\text { Benign/ } \\
\text { Malignant (n) }\end{array}$ \\
\hline No & $61.5 \pm 13.8$ & $24 / 10$ & $3 / 31$ \\
\hline Yes & $62.7 \pm 12.6$ & $323 / 183$ & $17 / 479$ \\
\hline p value & 0.578 & 0.469 & 0.130 \\
\hline $\begin{array}{l}\text { Grade of wall } \\
\text { thickening }\end{array}$ & Age (years) & $\begin{array}{l}\text { Male/Female } \\
(\mathrm{n})\end{array}$ & $\begin{array}{l}\text { Benign/ } \\
\text { Malignant }(\mathrm{n})\end{array}$ \\
\hline Normal $(0-5 \mathrm{~mm})$ & $62.4 \pm 13.0$ & $24 / 10$ & $3 / 31$ \\
\hline Moderate $(5-20 \mathrm{~mm})$ & $62.6 \pm 11.5$ & $48 / 15$ & $2 / 59$ \\
\hline Severe $(20-60 \mathrm{~mm})$ & $64.4 \pm 11.9$ & $27 / 16$ & $1 / 41$ \\
\hline $\begin{array}{l}\text { Diffuse wall } \\
\text { thickening }\end{array}$ & $62.5 \pm 12.9$ & $249 / 152$ & $14 / 380$ \\
\hline p value & 0.833 & 0.147 & 0.528 \\
\hline
\end{tabular}

\section{DISCUSSION}

To the best of our knowledge, no prospective clinical trials were conducted, and consensus clinical guidelines reported, to resolve the dilemma regarding the management of the patients with gastrointestinal wall thickening on $\mathrm{CT}$. Moreover, the use of CT for non-specific gastrointestinal symptoms such as dyspepsia, weight loss, unexplained change in bowel habits, bloating and abdominal cramps, has increased significantly over the last decade due to its wide availability [13]. Therefore, a thickened gastrointestinal wall has become a common finding in the daily practice of clinicians and these typically consult gastroenterology or general surgery in these cases. As a result, these patients undergo invasive procedures, such as endoscopy or colonoscopy, and bear the potential risks of these investigations
[14].

In our study, dyspepsia was the leading complaint in patients undergoing endoscopic procedures, whereas an unexplained change in bowel habits was the leading complaint in those undergoing colonoscopies. The increased volume of patients with complaints of chronic diarrhea or constipation and dyspepsia, raises the question of endoscopic evaluations as part of the diagnostic workup regarding these increasingly prevalent complaints [15]. On the other hand, for patients with digestive complaints, endoscopic evaluations have set the gold standard. Wood et al. analyzed 300 consecutive patients with digestive complaints and concluded that an endoscopy was unlikely to uncover a diagnosis to explain altered bowel habits or dyspepsia [16]. However, they recommended an initial non-invasive workup, such as a CT scan, as a reasonable option to identify a likely diagnosis. Some clinical studies investigated the association between an incidental finding of gastrointestinal wall thickening on CT scan and endoscopic findings $(2,3,9-12,14,16)$.

However, most of these studies did not analyze the symptomatology of the patients. In our study, we reviewed the gastrointestinal symptoms and chief complaints of our patients. Al-Khowaiter et al. retrospectively evaluated the clinical and endoscopic findings of patients previously reported to have bowel wall thickening on CT [17]. They reported that $24 \%$ of these patients had normal colonoscopic findings. In our series, only $4,7 \%$ of the endoscopic procedures and $1,5 \%$ of the colonoscopic procedures revealed normal results. On the other hand, $95,3 \%$ of the endoscopies and $96,5 \%$ of the colonoscopies elucidated a premalignant or malignant lesion. This relatively high premalignant and malignant lesion detection rate in our study can be attributed to the fact that our institution is a tertiary referral center for patients with gastrointestinal diseases. Additionally, in our study, the mean patient

was higher than the mean age of the study patients of the study population of Al-Khowaiter et al. [17]. Since the gastrointestinal malignancy rates increase with increasing patient age and gastrointestinal malignancies are most frequently diagnosed in the sixth and seventh decades, this 
fact should have contributed to our relatively higher gastrointestinal malignancy detection rate.

Our analysis revealed that CT and colonoscopic findings overlapped in $79,8 \%$ of the patients. Stermer et al. reported that among twelve cases with a diverticular disease diagnosed by colonoscopy, only eight had colonic wall thickening on CT [18]. Cai et al. reviewed the patients with incidental radiological findings of gastrointestinal wall thickening who subsequently underwent endoscopic procedures [19]. Their study demonstrated significant colonoscopic abnormalities in the sigmoid colon and rectum in $96 \%$ of patients with the radiological finding of wall thickening in the exact location. Similarly, endoscopic findings overlapped with CT in $66,3 \%$ of the patients in this study.

Among our patients, $95,3 \%$ were found to have a malignant pathology. In the literature, the accuracy for diagnosing gastric cancer in preoperative CT scans was reported to be in the range of $69-85 \%$. However, this accuracy level decreased to 26$53 \%$ in patients with the early stages of gastric malignancies. Also, Akbas et al. noted that the antropyloric region was challenging to evaluate regarding increased wall thickness associated with gastric malignancies due to its anatomical and physiological characteristics [3]. The peristaltic movements in this region and the physiological thickness of the antral smooth muscle can be confounding.

In our study, the appearance of a thickened gastrointestinal wall on the CT scan was not associated with an increased malignancy rate. This finding might be due to the high malignancy rate in our series. Moreover, the grade of wall thickening was also not associated with malignant disease. In their retrospective study, Tongdee et al. measured the wall thickness in patients with and without gastrointestinal malignancy as 16.64 and 5.68 , respectively [20]. The difference was found to be statistically significant between the groups. The same study utilized a ROC curve analysis to determine the optimal cut-off value and suggested a $10 \mathrm{~mm}$ cut-off point for differentiating malignancy. Our study took a cut-off point of $5 \mathrm{~mm}$, as reported in the literature [21].

Our study has some limitations which need to be considered while evaluating its findings. First, it is a retrospective study. Second, it bears a risk of selection bias since all patients presenting with gastrointestinal complaints do not automatically undergo abdominal CT scans. As a result of this approach, it can be stated that patients who underwent an abdominal CT scan and were included in our study may have had more severe findings and more severe disease. Third, the indications of ordering an abdominal CT scan in patients with gastrointestinal symptoms are not identified. Also, it is known that CT measurement of gastrointestinal wall thickness can be affected by some parameters such as distention and slice increments of the CT scan. These variables may have led to inter-observer differences in these measurements. Fourth, the time interval between abdominal CT scan and endoscopic or colonoscopic investigations was not standard. Therefore, the disease processes leading to wall thickening detected on CT scans might have partially or entirely healed in cases with long intervals.

Despite these limitations, we suggest performance of endoscopic or colonoscopic evaluations in patients with gastrointestinal wall thickening in CT scans since the diagnostic and predictive accuracy are limited when a single test like CT is used.

\section{CONCLUSIONS}

Endoscopic-colonoscopic evaluations should be performed in patients with gastrointestinal wall thickening in CT scans, since the diagnostic and predictive accuracy are limited when a single test like CT is used.

Conflict of Interest: The authors declare no conflict of interest related to this article.

Funding sources: The authors declare that this study has received no financial support

Ethics Committee Approval: Health Sciences University Dışkapı Yıldırım Beyazıt Training and Research Hospital Clinical Research Ethics Committee, 12.11.2018 ve Karar No: 56/12

Peer-review: Externally and internally peer reviewed.

\section{REFERENCES}

Bhatt A, Yang X, Karnik N, Sill A, Kowdley G. Use of Computerized Tomography in 
Abdominal Pain. Am Surg. 2018;84(6):1091-96. PMID: 29981654.

2. Min SB, Nylund CM, Abbas MI, Carter M, Olsen CH, Biko DM, Goldman MD. Thickened gastrointestinal wall findings on computed tomography in children: a reason for endoscopy? J Pediatr Gastroenterol Nutr. 2013;57(3):305-10. doi: 10.1097/ MPG.0b013e3182952eaa.

3. Akbas A, Bakir H, Dasiran MF, Dagmura H, Daldal E, Ozsoy Z, Ozmen Z, Demir O, Okan I. Colonic Wall Thickening Reported in Abdominal CT: Does It Always Imply Malignancy? Gastroenterol Res Pract. 2019;2019:2492097. doi: $10.1155 / 2019 / 2492097$

4. Atila K, Güler S, Gönen C, Sarıoğlu S, Bora S. Benign solitary cecal ulcer: a condition that mimics plastron appendicitis. Ulus Travma Acil Cerrahi Derg. 2010;16(6):579-81. PMID: 21153957.

5. Bostancı MT, Seki A, Avcı A, Çimen S, Gökçe A, Şahin M, Yılmaz KB, Ergül Z. "Difficult" colorectal polyps resected surgically. Tepecik Eğit Hast Derg. 2018;28(2):127 130

6. Duncan JE, Sweeney WB, Trudel JL, Madoff RD, Mellgren AF. Colonoscopy in the elderly: low risk, low yield in asymptomatic patients. Dis Colon Rectum 2006;49(5):646-51. doi: 10.1007/s10350-005-0306-3.

7. Rathore F, Sultan N, Byrne D. Tolerance of colonoscopy and questioning its utility in the elderly population. Ir Med J. 2014;107(8):247. PMID: 25282969.

8. Cimen S, Guler S, Panek R, Alwayn I. Gastrointestinal stromal tumour in a recipient with kidney transplantation. BMJ Case Rep. 2015;2015 bcr2014207178. doi: 10.1136/bcr-2014-207178

9. Fernandes T, Oliveira MI, Castro R, Araújo B, Viamonte B, Cunha R. Bowel wall thickening at CT: simplifying the diagnosis. Insights Imaging. 2014:5(2):195-208. doi: $10.1007 / \mathrm{s} 13244-013-0308-y$.

10. Daniel F, Alsheikh M, Ghieh D, Hosni M, Tayara Z, Tamim H, Abi-Ghanem AS, El-Merhi F. Bowel wall thickening on computed tomography scan: Inter-observ er agreement and correlation with endoscopic findings. Arab J Gastroenterol. 2020;21(4):219-223. doi: 10.1016/i.ajg.2020.04.012.

11. Khairnar H, Ingle M, Chauhan S, Pipalia N, Sawant P, Pandey V. Shukla A. Correlation of Computed Tomography of Colonic Wall Thickening with Colonoscopy. $J$ Assoc Physicians India. 2019;67(4):18-21. PMID: 31299832

12. Akbas A, Bakir H, Dasiran MF, Dagmura H, Ozmen Z, Yildiz Celtek N,Daldal E, Demir O,Kefell A, Okan I. Significance of Gastric Wall Thickening Detected in Abdominal CT Scan to Predict Gastric Malignancy. J Oncol. 2019;2019:8581547. doi: $10.1155 / 2019 / 8581547$

13. Fagerström A, Paajanen $\mathrm{P}$, Saarelainen $\mathrm{H}$, Ahonen-Siirtola M, Ukkonen M, Miettinen $P$, Paajanen $\mathrm{H}$. Non-specific abdominal pain remains as the most common reason for acute abdomen: 26-year retrospective audit in one emergency unit. Scand Gastroenterol. 2017:52(10):1072-1077. doi: 10.1080/00365521.2017.1342140.

14. Iadicola D, De Marco P, Bonventre S, Grutta EM, Barletta G, Licari L, Gulotta G. Bowel wall thickening: inquire or not inquire? Our guidelines. G Chir. 2018;39(1):4144. doi: 10.11138/gchir/2018.39.1.041.

15. Mari A, Abu Backer F, Mahamid M, Amara H, Carter D, Boltin D, Dickman R. Bloating and Abdominal Distension: Clinical Approach and Management. Adv Ther 2019;36(5):1075-1084. doi: 10.1007/s12325-019-00924-7.

16. Wood C, Zeno WC, Jarski R, Sendelbach M, Bischoff R, et al. Diagnostic Yield for Endoscopy in Patients with Altered Bowel Habits. Gastroenterol Hepatol Open Access 2017;6(2):44-7. DOI: 10.15406/ghoa.2017.06.00187

17. Al-Khowaiter SS, Brahmania M, Kim E, Madden M, Harris A, Yoshida EM, Gray JR. Clinical and endoscopic significance of bowel-wall thickening reported on abdominal computed tomographies in symptomatic patients with no history of gastrointestinal disease. Can Assoc Radiol J. 2014;65(1):67-70. doi: 10.1016/j. carj.2012.01.002.

18. Stermer E, Lavy A, Rainis T, Goldstein O, Keren D, Zeina AR. Incidental colorecta computed tomography abnormalities: would you send every patient for a colonoscopy? Can J Gastroenterol. 2008;22(9):758-60. doi: 10.1155/2008/901250.

19. Cai $Q$, Baumgarten DA, Affronti JP, Waring JP. Incidental findings of thickening luminal gastrointestinal organs on computed tomography: an absolute indication for endoscopy. Am J Gastroenterol. 2003;98(8):1734-7. doi: 10.1111/j.1572 0241.2003.07604.x.

20. Tongdee R, Kongkaw L, Tongdee T. A study of wall thickness of gastric antrum comparison among normal, benign and malignant gastric conditions on MDCT scan. J Med Assoc Thai. 2012;95(11):1441-8. PMID: 23252211.

21. Wiesner W, Mortelé $\mathrm{KJ}, \mathrm{Ji} \mathrm{H}$, Ros PR. Normal colonic wall thickness at $\mathrm{CT}$ and its relation to colonic distension. J Comput Assist Tomogr. 2002;26(1):102-6. doi: 10.1097/00004728-200201000-00015.

\begin{tabular}{|l|l|}
\hline Author / ORCID & Authorship Contrubition \\
\hline $\begin{array}{l}\text { Mehmet Alperen Avcı } \\
0000-0003-3911-2686\end{array}$ & $\begin{array}{l}\text { Consept, Design, Materials, } \\
\text { Practices, Data collection, Processing, } \\
\text { Interpretation, Literatüre Review, } \\
\text { Manuscript Writing, Final approval }\end{array}$ \\
\hline $\begin{array}{l}\text { Engin Ölçücüoğlu } \\
\text { 0000-0003-0756-3247 }\end{array}$ & $\begin{array}{l}\text { Consept, Design, Materials, Practices, } \\
\text { Interpretation, Critical Review, } \\
\text { Manuscript Writing, Final approval }\end{array}$ \\
\hline $\begin{array}{l}\text { İsmail Oskay Kaya } \\
\text { 0000-0002-1864-896X }\end{array}$ & $\begin{array}{l}\text { Consept, Design, Analysis, } \\
\text { Interpretation, Critical Review, } \\
\text { Processing }\end{array}$ \\
\hline $\begin{array}{l}\text { Cem Azılı } \\
\text { 0000-0003-3661-2052 }\end{array}$ & $\begin{array}{l}\text { Consept, Design, Materials, Practices, } \\
\text { Interpretation, Critical Review, }\end{array}$ \\
\hline Metin Aydın & $\begin{array}{l}\text { Consept, Design, Search, Analysis, } \\
\text { Co00-0001-5638-0151 }\end{array}$ \\
\hline $\begin{array}{l}\text { Serra Özbal Güneş } \\
\text { 0000-0003-1019-9925 }\end{array}$ & $\begin{array}{l}\text { Materials, Practices, Data collection, } \\
\text { Final approval, Analysis }\end{array}$ \\
\hline
\end{tabular}

